\title{
Artelogie
}

Recherche sur les arts, le patrimoine et la littérature de l'Amérique latine

5 | 2013

Femmes créatrices en Amérique latine : le défi de synthétiser sans singulariser

\section{Tramas feministas na arte contemporânea brasileira e argentina: Rosana Paulino e Claudia Contreras}

Luana Saturnino Tvardovskas

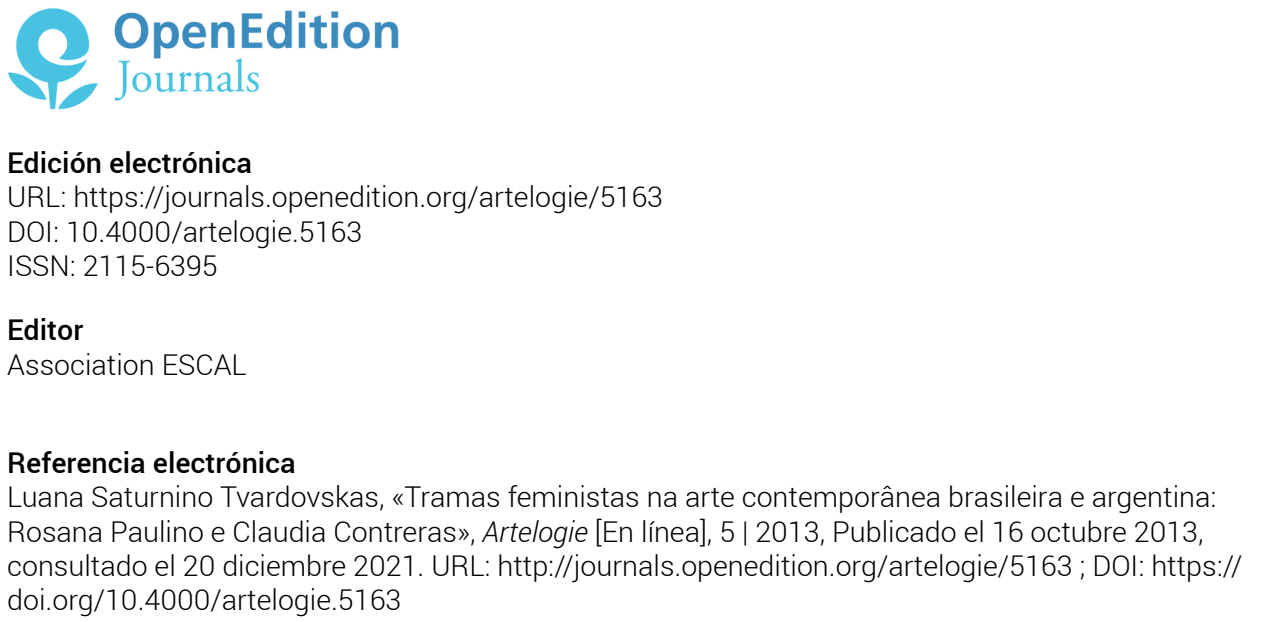

Este documento fue generado automáticamente el 20 diciembre 2021.

Association ESCAL 


\title{
Tramas feministas na arte contemporânea brasileira e argentina: Rosana Paulino e Claudia Contreras
}

\author{
Luana Saturnino Tvardovskas
}

\section{Introdução: perspectivas feministas na história da arte latino-americana}

1 Esse artigo propõe analisar as produções de duas mulheres artistas contemporâneas cujas obras contestam práticas misóginas, apresentando um espaço privilegiado de intersecção com o pensamento feminista, por confrontar as verdades estabelecidas e problematizar a constituição das subjetividades femininas. As experimentações realizadas pela artista brasileira Rosana Paulino (São Paulo, 1967-) e pela argentina Claudia Contreras (Buenos Aires, 1956-) oferecem inúmeras pistas para a compreensão dessas práticas artísticas na América Latina e, mais do que percebê-las como práticas isoladas, é possível inseri-las num contexto de tensões culturais e de intervenções críticas que atravessam diferentes criadoras na atualidade. Nesse sentido, investigo como suas obras formulam críticas culturais contundentes, também considerando que a arte contempla zonas de sensibilidade que nem sempre são priorizadas pelo pensamento científico tradicional (TELLES, 2008:116).

2 A arte, em suas mais variadas formas, pode ser interpretada como uma prática de autoconstituição de si, sobretudo na contemporaneidade, em que a tarefa do artista ganha contornos autobiográficos, como espaço de expressão de posições éticas, estéticas, políticas e também afetivas (CHIRON; LELIÈVRE, 2012 e ARFUCH, 2010). A arte pode ser vista, assim, como um espaço do dizer verdadeiro no mundo contemporâneo, porque guiada por um ethos de dar forma ao ser, na medida em que o artista expressa sua percepção e concepções sobre a vida social, pretendendo criar um estilo próprio 
(FOUCAULT, 2011). Outro dos elementos que permitem esta aproximação é seu potencial de transformação e crítica histórica aos modelos impostos e normas sociais. Um artista compõe imagens para um embate: imagens-pensamento que estão destinadas a afetar o espectador com problemas, medos, prazeres, dúvidas ou êxtases perpassados por sua visão individual. Os artistas são eles mesmos constituídos por normas de gênero, assim como por referências religiosas, raciais, de classe e geração (POLLOCK, 2007: 48). No entanto, podem confrontar tais proposições e discutir as imposições e modelos binários, utilizando a arte como um espaço de elaboração de suas práticas individuais e coletivas.

3 Diferentes artistas contemporâneas têm captado e recriado algumas das importantes problemáticas feministas de nossa época, produzindo discursos na cultura que são valiosos espaços de compreensão sobre a atualidade. Trazer à tona suas próprias experiências em chaves autobiográficas, expor seus corpos, desejos, confrontar a repressão ou violência sobre sua história e sexualidade, são alguns dos elementos que, dentro de uma grande variedade de propósitos, podem ser pensados como práticas feministas de si nas obras de arte destas mulheres. Imagens artísticas são, ainda, modos de tomar consciência sobre o que antes as mulheres consideravam patologizações individuais, abordando esses temas enquanto processos culturais e sociais de opressão. ${ }^{1}$ Suas obras discutem também os discursos dominantes como a misoginia, o racismo, o preconceito de classe e heretossexismo, que muitas vezes objetificam e marginalizam indivíduos e grupos sociais, considerando-os desviantes por meio de separações entre o normal e o anormal. Pretende-se, desse modo, problematizar a seguir como as obras de Paulino e Contreras questionam esses investimentos sobre as subjetividades femininas, para que as verdades universais possam ser desmontadas e surjam espaços alternativos para a construção de saberes (FOUCAULT, 1994). Pensando politicamente, é cada vez mais urgente, então, um conhecimento situado e incorporado que deixe de lado os pseudo-universalismos e uma visão falogocêntrica do mundo. ${ }^{2}$ Trata-se de ensaiar propostas mais múltiplas e fragmentadas, que tomem em conta a diversidade de experiências culturais e históricas e não apenas a do sujeito masculino, branco e ocidental - estandarte dos discursos verdadeiros (POLLOCK, 2007).

4 Em diferentes países da chamada América Latina, o desenrolar das ditaduras cívicomilitares ritmou diferentemente a ampliação do movimento feminista e, consequentemente, teve efeitos também outros no campo artístico (ALVAREZ, 2003, web). Nos casos brasileiro e argentino, por exemplo, uma maior liberdade das discussões do movimento de mulheres ganhou forma apenas com o fim dos regimes autoritários. Assim, não é viável ou produtivo ensaiar uma periodização para a crítica feminista da arte no Brasil, Argentina, Chile ou Uruguai buscando que esta seja coincidente com as efervescências europeias e, sobretudo, com a norte-americana da década de 1970 em diante. Ainda que mulheres artistas em períodos ditatoriais latinoamericanos possam haver demonstrado interesse nos temas do feminismo, tais empreitadas não chegaram a constituir-se como um movimento nas artes visuais. Essa especificidade exige, assim, um olhar mais afinado com as urgências políticas dos anos de ditaduras militares. Apenas a partir dos anos de saída desses regimes violentos o feminismo impactou mais amplamente na indústria cultural e também no terreno das artes.

5 Outro ponto a ser considerado é a própria natureza do mercado da arte em países como Brasil e Argentina, mesmo que ocupem cada vez mais um espaço de destaque no mundo 
globalizado, não se pode assumir que os interesses capitalistas ajam em igual proporção nesses mercados emergentes (FIALHO, 2005:690). Há também certa dificuldade de encontrarmos artistas brasileiras que se posicionem como ativistas do feminismo e essa aparente "negação" evidencia como são complexas as relações de identificação, mas também de aceitação das temáticas de gênero pelo próprio mercado (TVARDOVSKAS, 2008: 200). Em realidade, as práticas feministas de diversas criadoras de países periféricos têm a característica de não se formular enquanto identitárias, ou seja, não "levantam bandeiras" no sentido mais óbvio da palavra feminista. Elas não se compreendem como um grupo, nem mesmo consideram como sua a tarefa de lutar contra o mercado institucional e os discursos canônicos que reincidentemente desvalorizam a produção feminina. Sua atuação está mais ao lado das poéticas feministas, na medida em que suas obras reinventam narrativas sobre o feminino e o masculino, desconstroem estereótipos misóginos e ironizam as práticas do poder. Ao mesmo tempo, a não articulação em termos políticos pode representar algum grau de apagamento das experiências ao longo do tempo e, também, gerar uma falta de transmissão sobre a importante luta das mulheres às artistas mais jovens.

Quando nos tornamos conscientes desses jogos do mercado, a tarefa de sublinhar as perspectivas críticas que se evidenciam no Brasil e Argentina mostra-se desafiante. As duas artistas aqui enfatizadas - pelas circunstâncias da crítica e do mercado de arte em seus países - não estão amparadas por grandes exposições com temáticas "feministas" ou por novos recortes e interpretações de gênero e parece haver nelas um intento de manter um espaço de liberdade ao abordar esses assuntos ainda marginais. Também poderíamos levar em conta que o mercado de arte ainda não se constitui com o mesmo furor apresentado nos EUA, França e Inglaterra e que, de fato, as temáticas advindas do feminismo que lá já foram amplamente incorporadas, ainda passeiam tímida e lentamente em nossos circuitos artísticos latino-americanos, sendo que há uma escassez de textos traduzidos para o português que se constituem como referência para novas abordagens da história da arte que considerem como fator a questão de gênero, assim como são poucos os críticos de arte que trabalham nessas perspectivas.

7 Como afirma a pesquisadora espanhola Estrella de Diego, em países periféricos como Brasil e Argentina, as problemáticas entre arte e gênero pautaram-se em muito pelas discussões pós-estruturalistas e pelo feminismo da diferença e, como resultado dessa apropriação mais tardia, ainda não houve nesses países uma extensa revisão do cânone como a princípio ocorreu nos escritos de língua inglesa, nem mesmo uma grande discussão ou rememoração sobre as artistas de outros períodos históricos movimentos que passam a ocorrer apenas mais recentemente (DE DIEGO, 2008).

8 A América Latina abarca uma vastidão de experiências, com multiplicidades e historicidades às vezes convergentes, outras vezes não: são "várias Américas Latinas, não apenas determinadas pelos contrastes geográficos, mas também pelos contrastes políticos, culturais e econômicos" (BRUIT, 2000:10). Quase sempre, esse é um conceito que nos une em um guarda-chuva de subdesenvolvimento, colonialismo, sucessivas ditaduras militares e ampla violência social, sexual e histórica. Nesse cenário, cruzar produções artísticas é uma tarefa de fabricação, de aproximação consciente por escolhas pessoais, mas que também políticas e éticas.

9 Essas pluralidades nos incitam a pensar a produção das mulheres artistas observando suas diferenças, como problematiza Griselda Pollock, ao propor uma prática teórica feminista que seja crítica dos discursos unitários e canônicos, produzindo novas e 
múltiplas narrativas sobre a arte e rompendo com falsas generalizações: "Las obras de arte demandan ser leídas como prácticas culturales que negocian los significados conformados por la historia y el inconsciente. Piden que se les permita cambiar la cultura en las que intervienen a través de ser consideradas creativas: poïtic y transformativas" (POLLOCK, 2010: 54). Nas próximas páginas, passaremos a enfatizar essas especificidades e fluxos próprios às obras de Rosana Paulino e Claudia Contreras, analisando como desconstroem estereótipos culturais, formulam críticas de conteúdo feminista e propõem novas interpretações para as relações de gênero na atualidade.

\title{
Rosana Paulino: mapeando a subjetividades das mulheres negras no Brasil
}

\author{
Tenho uma cicatriz incandescente de dor \\ Mas é só por dentro \\ Por fora desenhei uma flor \\ Cristiane Sobral
}

10 No Brasil, diferentemente de um movimento artístico feminista organizado - por exemplo, como ocorreu com força de ativismo político nos EUA e, mais recentemente, na França ou ainda no México -, os diálogos com temas relativos às mulheres aconteceram de maneira mais individualizada e autônoma. Hoje, há toda uma geração de jovens artistas brasileiras cuja produção foi influenciada direta ou indiretamente pelas problemáticas de gênero. Ainda que não se intitulem feministas - desviando-se de qualquer fixidez identitária - muitas delas incorporam e discutem essas questões, como atenta Heloisa Buarque Hollanda: "Enfim, essas novas artistas, que dizem não querer mais nada com o feminismo, são o maior exemplo da vitória arrasadora das conquistas feministas" (HOLLANDA, 2006: 97). São transgressoras no campo do imaginário, das práticas e do simbólico e produzem arte com um conteúdo político específico ao reciclar imagens da vida cotidiana e da experiência feminina, em campos expandidos da arte. Expandidos porque se situam em zonas instáveis entre escultura e objetos; entre vídeo e áudio; entre escrita, desenho e gravura; entre fotografia e pintura; entre instalação e performance. São propostas plurais que rompem determinações ou limites dos gêneros artísticos, respondendo mais diretamente às problemáticas vividas do que a terrenos definidos. De todas as formas, a entrada massiva de mulheres no circuito artístico contemporâneo não deixa de ser um dos indícios da enorme transformação cultural advinda dos feminismos nesse país.

11 Rosana Paulino é gravadora, vive e trabalha em São Paulo. Entre os anos de 1993 e 1995 fez estágio no Ateliê de Restauro de obras de Arte em suporte de papel do Museu de Arte Contemporânea da Universidade de São Paulo (MAC/USP). Em 1995 tornou-se bacharel em Gravura pela Escola de Comunicação e Artes da USP. Também fez especialização em gravura pelo London Print Studio, em Londres, por meio da Bolsa APARTES/CAPES e possui doutorado em Artes Plásticas pela ECA/USP.

A artista adentra o campo de discussão do gênero e da etnicidade e trabalha com as imagens de mulheres negras e mestiças, por vezes remetendo ao espaço doméstico e a funções sociais específicas, como a tecelã e a operária (FAZZOLARI, 2006: web). A mãe da artista trabalhou como costureira na periferia de São Paulo - até hoje Paulino vive no mesmo bairro onde passou a infância, na Freguesia do ó - e cotidianamente ela conviveu com essa prática, assim como com referências advindas da religião Umbanda. 
Paulino discute a construção da subjetividade da mulher negra em muitas de suas obras, focando como é na intimidade que as práticas de submissão forjam-se e mantêm-se. 0 elemento biográfico, em sua produção, cruza-se com imagens e memórias coletivas sobre a relação das mulheres no espaço doméstico, por vezes permeada de silêncio e humilhação subjetiva. O problema do preconceito racial e sexual é enfrentado pela artista, que o aborda em sua dor e crueldade, como um meio de intervir nas práticas estabelecidas, sensivelmente usando a arte para abrir outros caminhos de constituição de si que sejam compostos por relações de liberdade e não de resignação.

Sobretudo a partir dos anos de 1990, muitas obras de mulheres passaram a interagir ainda mais fortemente na transformação do imaginário misógino, respondendo tanto à maior abertura cultural derivada do fim dos governos autoritários, como à crescente visibilidade e legitimidade alcançadas pelos movimentos feministas. Nesse trânsito complexo, nos anos de 1980 e de 1990 emerge uma produção artística que, numa dupla via, aborda com honestidade a relação entre a história pessoal e o imaginário brasileiro. Trabalhos subversivos que desconstroem os enaltecimentos à nação, mas que não deixam de compreender que o "pessoal é político", como destacado pelo pensamento feminista. Para Katia Canton, em várias produções de mulheres artistas no final do século XX há uma "manipulação de materiais diretamente relacionados ao universo da manualidade doméstica, como tecidos, bordados, travesseiros, mantas e brocados", que discutem os ícones dessa domesticidade, formulando contundentes críticas culturais (CANTON, 2001: 89). Podemos destacar outras artistas brasileiras contemporâneas que elaboraram, principalmente a partir de 1990, questões sensíveis ao corpo e ao cotidiano femininos de um ponto de vista crítico, como Ana Miguel (1962-), Cristina Salgado (1957-), Fernanda Magalhães (1962-), Rosângela Rennó (1962-), Márcia X. (1959-2005), Rosana Palazyan (1963-), Brígida Baltar (1959-), Nazareth Pacheco (1961-) e Rivane Neuenschwander (1967-).

14 Paulino, que inicia sua produção na década de 1990, dialoga com a condição sóciohistórica brasileira ao mesmo tempo em que aborda as memórias coletivas e individuais que marcam sua construção subjetiva. Nesse sentido, trabalha com imagens de uma sensibilidade feminina culturalmente determinada, sobretudo questionando os lugares sociais destinados às mulheres negras: "Manipulando a diferença na arte, Paulino expandiu suas "retratospectivas" que trabalhavam com antigos retratos familiares, falando de um universo negro e feminino, para lidar com novas instalações utilizando suportes originais" (CANTON, 2001: 90). 
Imagem 01 - Rosana Paulino, Parede da Memória (detalhe), 1994

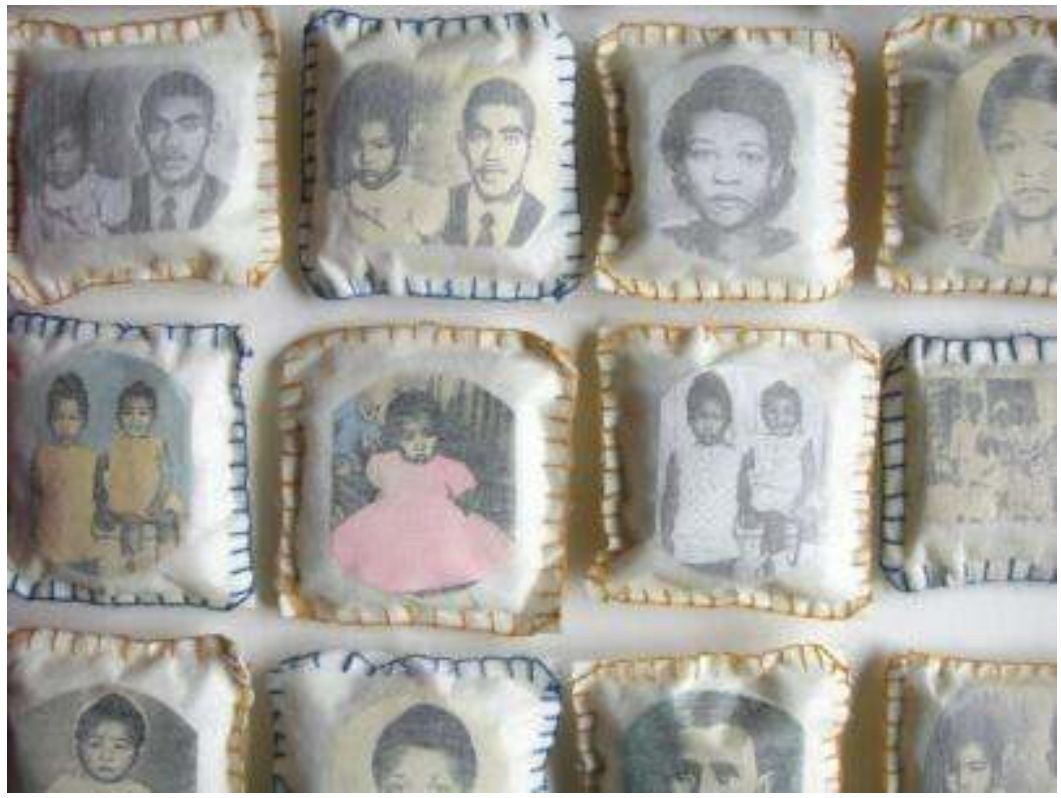

Tecido, microfibra, xerox, linha de algodão e aquarela. 8,0 × 8,0 × 3,0 cm cada elemento

Imagem 02 - Rosana Paulino, Desenho da série Carapaça de Proteção, 2003

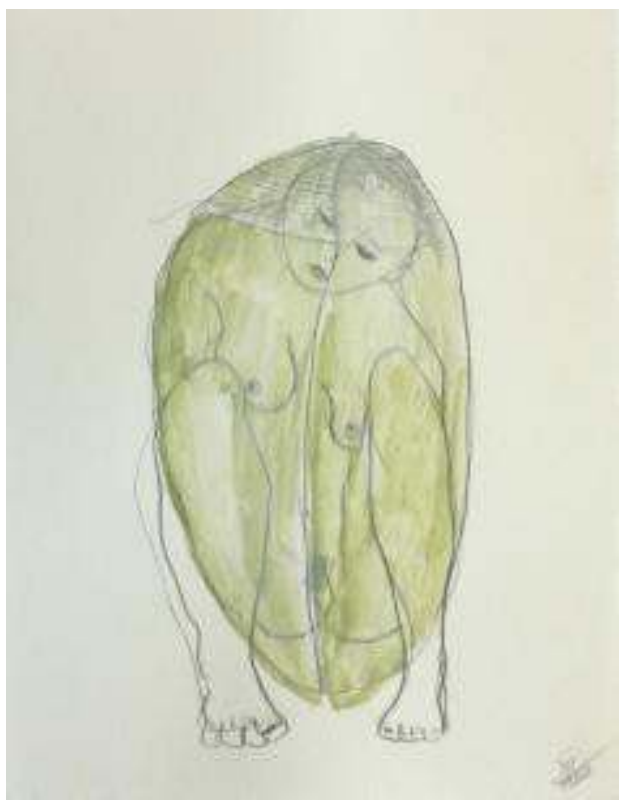

Seus patuás presentes na instalação Parede da memória (1994) remetem a uma prática de proteção presente no sincretismo afro-católico e à ligação pessoal de sua família com o a Umbanda, o que impactou fortemente sua visualidade. Essas referências que combatem o apagamento das tradições africanas e também das memórias negras indicam um campo que interessa diretamente a essa artista. Cruza, desse modo, representações do passado escravocrata e da experiência da opressão vivenciada hoje por grande parte da população negra. São mesclas de memórias, de biografia, mas também de lendas, de mitos e de um legado histórico dramático. Assim, sua produção é 
também um testemunho de uma história que reage ao esquecimento, constituindo uma crítica cultural contemporânea.

O racismo, a violência doméstica, os conflitos com o próprio corpo e as pressões para adequar-se aos padrões de beleza bombardeados cotidianamente, são outros temas que também ganham destaque. Por meio de seus desenhos, que sempre ocuparam um papel especial na poética visual da artista, uma percepção fantasmática do corpo ganha forma. Surgem seres disformes, imagens de bonecas, crianças e até mesmo de abortos, figuras femininas com inúmeros seios, muitas vezes remetendo a metamorfoses animais, que carregam grande impacto sensível, como na série Carapaça de Proteção (2003). Paulino compõe em cada uma de suas imagens uma relação de estranhamento com os corpos e com a sexualidade, imprimindo sensações variáveis nessas representações culturalmente binárias e naturalizadas e esse potencial de desterritorialização das imagens estáveis da diferença sexual e dos papéis de gênero é um ponto central para a análise aqui desenvolvida (DELEUZE e GUATTARI, 1997).

$\mathrm{Na}$ cultura brasileira o corpo das mulheres negras é alvo sistemático de discursos brutais e machistas, explorado em imagens publicitárias, no carnaval e no turismo como algo que pode ser dominado e possuído, especialmente sua sexualidade. Paulino reage a esses modelos ao denunciar os atributos historicamente a elas destinados, marcando sua arte com "traços de revolta", como apontou Tadeu Chiarelli (CHIARELLI, 1999: 43). Nesse país, a produção artística que debate o racismo não recebe ainda grande destaque ou elaboração teórica e é também notável a discrepância entre a quantidade de artistas brancos e negros no sistema artístico. Tomando em conta o já consolidado movimento feminista de mulheres negras no Brasil e também as reivindicações por maior reconhecimento vindas de artistas negras de muitas partes do mundo, salta aos olhos o espaço reduzido recebido pelas mesmas no cenário da arte contemporânea brasileira, ao menos no terreno das artes plásticas (BRITO, 1997: web). Num período pós-colonial, temos a responsabilidade política de abordar esses temas ao constatar que a arte continua prioritariamente branca, masculina e baseada em modelos norte-americanos e europeus. Nesse sentido, algumas das problemáticas e contradições existentes desde o princípio entre a arte e a crítica feminista foram apontadas pelas feministas negras e lesbianas, que se contrapuseram às tentativas de identificar um "imaginário feminino" ou uma experiência feminina global. Criticaram, assim, as tentativas de circunscrever a identidade feminina como uma categoria universal (RECKITT e PHELAN, 2006: 134).

Em diversas obras, Paulino utiliza linhas e agulhas, tecidos e objetos corriqueiros ou do âmbito popular. Acerca do procedimento de apropriação e ressignificação de elementos pouco valorizados e tipicamente associados ao universo feminino, ela comenta: " $O$ fio que torce, puxa, modifica o formato do rosto, produzindo bocas que não gritam, dando nós na garganta. Olhos costurados, fechados para o mundo e, principalmente, para sua condição de mundo" (PAULINO, 1997: 114). 


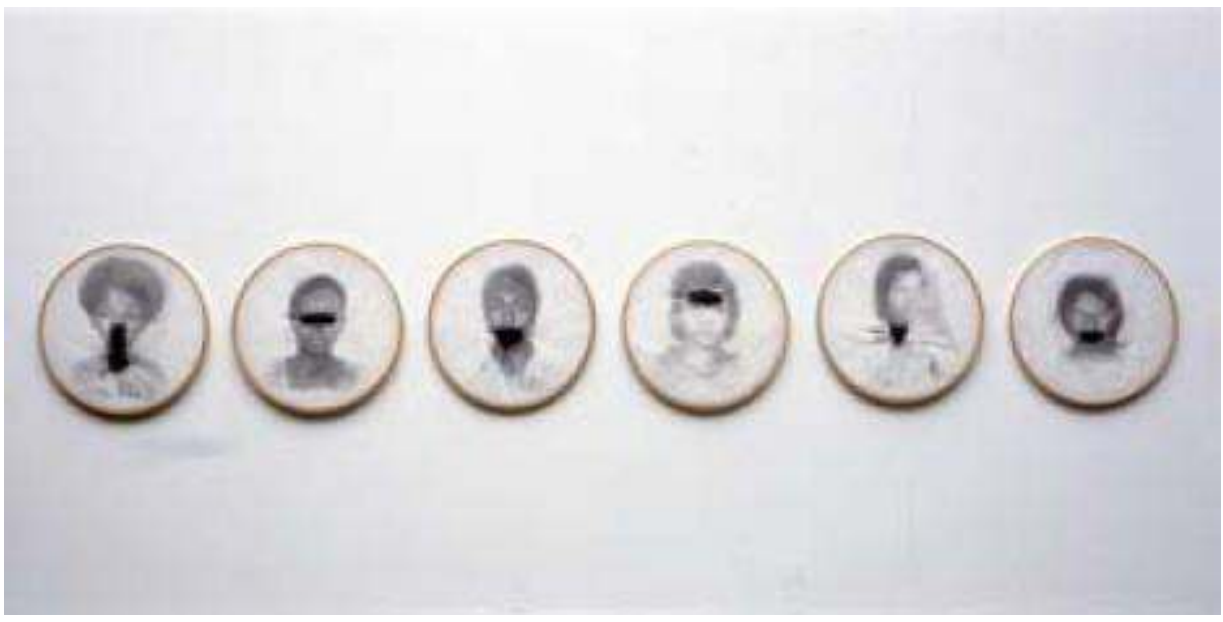

Imagem transferida sobre tecido, bastidor e linha de costura - 30,0 cm diâmetro

Imagem 04 - Rosana Paulino, Bastidores, 1997

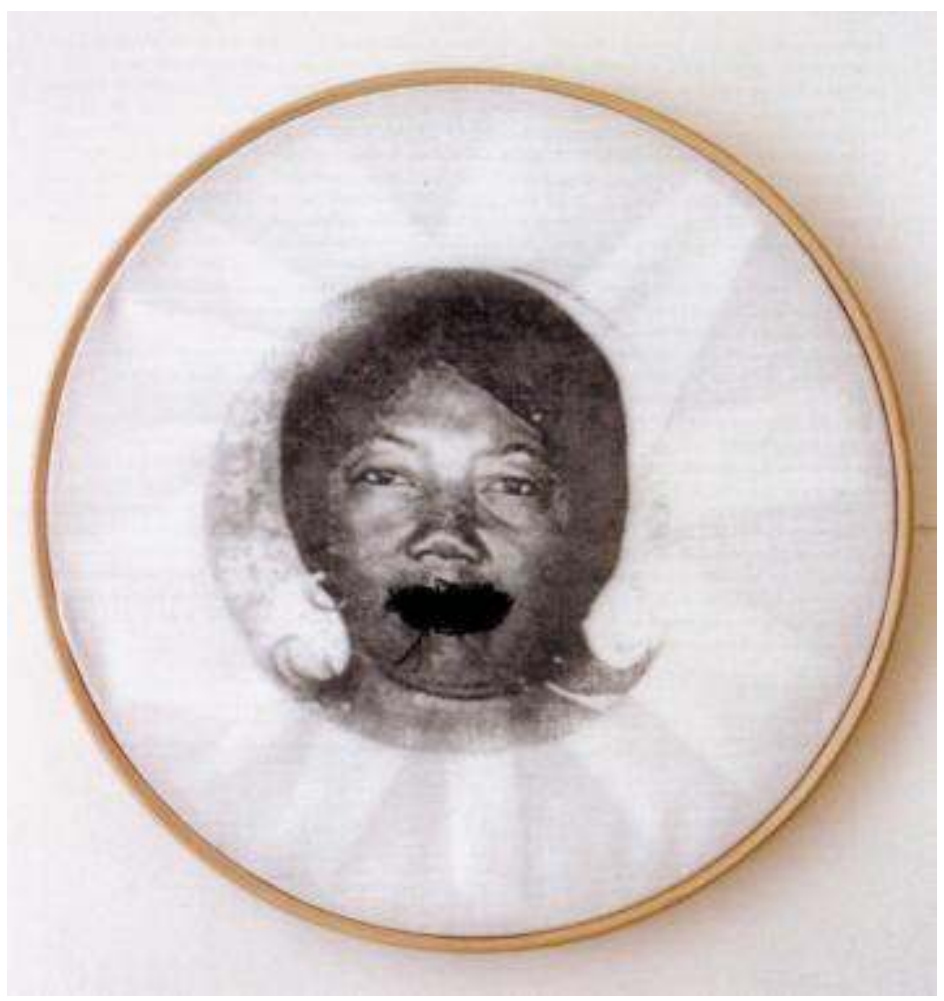

Detalhe

Em suas palavras, Paulino refere-se à obra Bastidores (1997) em que seis imagens de mulheres negras têm as bocas, olhos, testa ou a garganta costurados grosseiramente em linha escura pela artista. Os bastidores são expostos lado a lado e a impressão em preto e branco dos rostos dessas mulheres é quase translúcida. A maior parte dessas imagens parece ser antiga, o que se nota pelas roupas e penteados. Outras possuem uma numeração típica de fotografias 3X4, que traziam a data acima do ombro. Bastidores são releituras de imagens preexistentes, de fotografias pessoais da artista, retratos de circunstâncias da vida cotidiana, mas que recebem uma leitura dramática e carregada 
de sentido, por meio do suporte onde estão expostas e do bordado realizado por Paulino.

O título da obra também sugere o tom do anonimato, daquilo que acontece em segredo, no universo doméstico e é agressivo às mulheres: bastidores são coisas íntimas e particulares, afastadas do espaço público. As imagens são bastante impactantes e remetem à opressão, à dor e ao desconforto, "contrapondo radicalmente o lado bucólico $e$ delicado do bordado com a violência doméstica contra as mulheres", como indica Canton (CANTON, 2001: 89-90).

21 Joedy Bamonte assinala a importância do procedimento da costura para a execução das obras de Paulino (2004). Em algumas séries da artista nota-se alguma referência aos fazeres artesanais: bordados, fios, tecidos etc. Em outras, como Tecelãs (2003), esta presença é ainda mais explícita, onde casulos de bichos-da-seda parecem metamorfosear-se em mulheres moldadas em barro. Estes elementos relacionam-se à história pessoal da artista, ao mesmo tempo em que promovem uma releitura do ambiente doméstico e de elementos típicos da experiência das mulheres na casa. Ana Paula Simioni também atenta ao procedimento do bordado como uma transgressão: " $A$ forma violenta com que as linhas incidem sobre os corpos negros suscitam a incômoda memória da experiência, um passado não resolvido da escravidão no Brasil. (...) são mulheres negras estampadas, amordaçadas, cegas, impedidas de ver, pensar, falar ou gritar que a artista expõe" (SIMIONI, 2010:13).

Imagem 05 - Rosana Paulino, Tecelãs, 2003

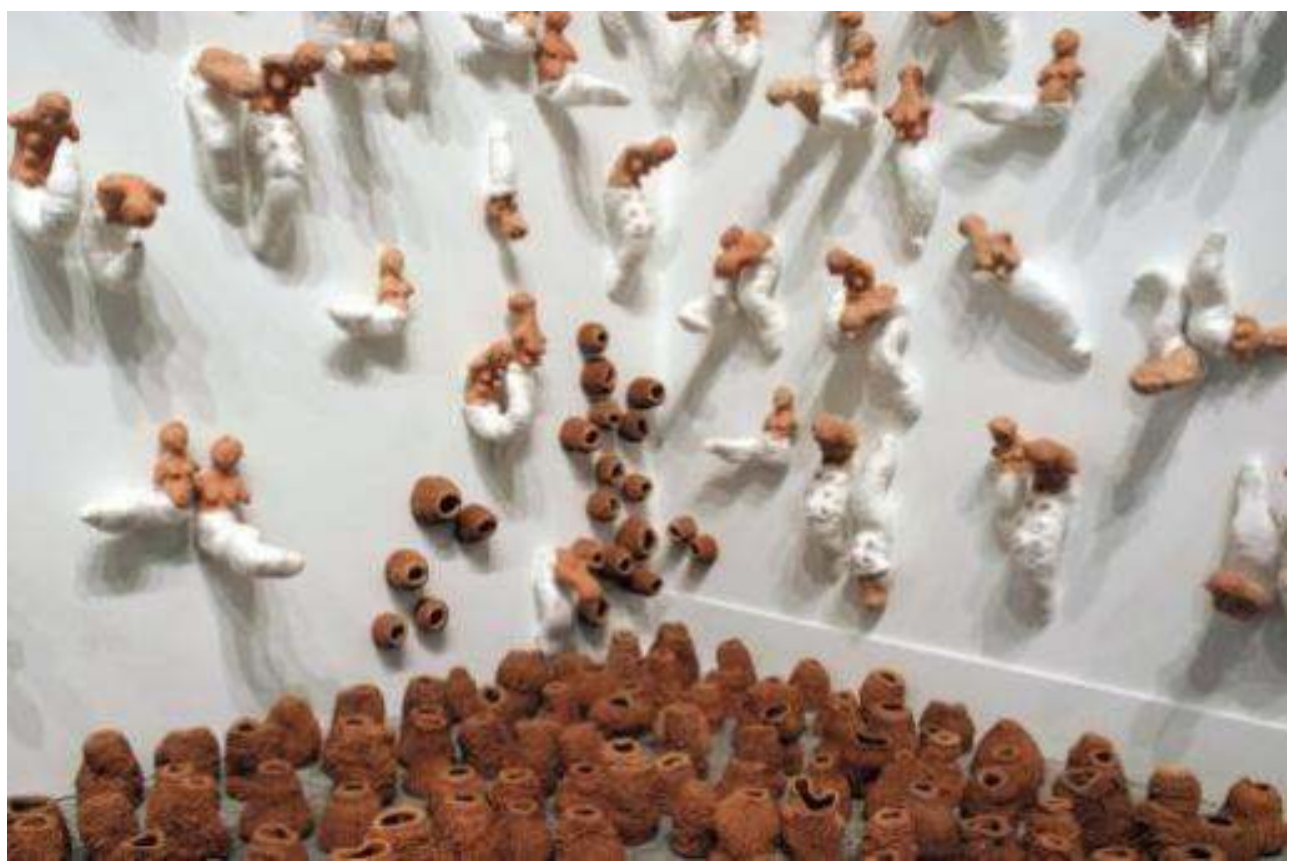

Vista da Instalação na IV Bienal do Mercosul - Faiança, terracota, algodão e linha sintética Dimensão variável

Uma possível leitura de uma das imagens da série Bastidores, em que a boca da figura feminina está costurada, remete ao cerceamento de uma mordaça ou máscara de ferro, como as que eram impostas aos escravos no Brasil, justificando-se que a tortura era necessária para impedir que falassem, bebessem álcool, comessem terra em tentativas desesperadas de suicídio ou, nas minas de carvão, para que não engolissem as pepitas 
de ouro: a chamada máscara de folha-de-flandres (AZEVEDO, 1988 e LARA, 1988). A imagem de Jacques Etiene Arago e N. Maurin, Castigo de escravos (1839/ coleção Museu Afro Brasil) é citada posteriormente pela artista em sua tese doutoral que explicita como, desta mulher, foram tiradas as possibilidades de expressão, além da sujeição a que foi submetida, sendo a ela imputada uma animalidade, evidente pela violência do instrumento de tortura (PAULINO, 2011: 49). Ao transitar entre imagens da crueldade da escravização africana no Brasil e a experiência contemporânea de opressão, a obra ressoa em práticas de controle que são cada vez mais atuais, como por meio da violência doméstica - as costuras, aqui, são "suturas sobre cortes profundos", como nota Jaremtchuk (JAREMTCHUK, 2007).

Imagem 06 - Mulher negra usando instrumento de tortura "máscara de folha-de-flandres". s/d

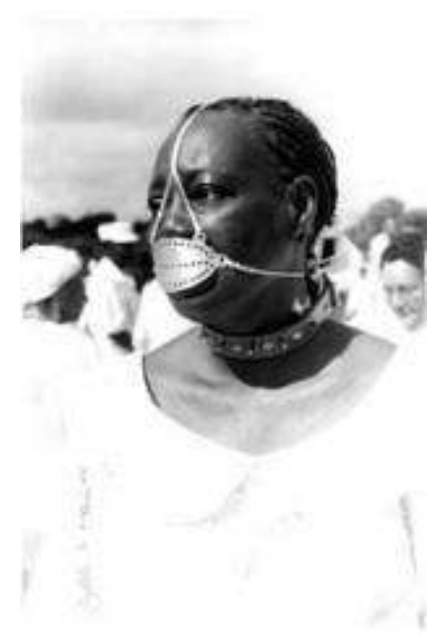

Imagem 07 - ARAGO, Jacques Etienne e MAURIN, N.

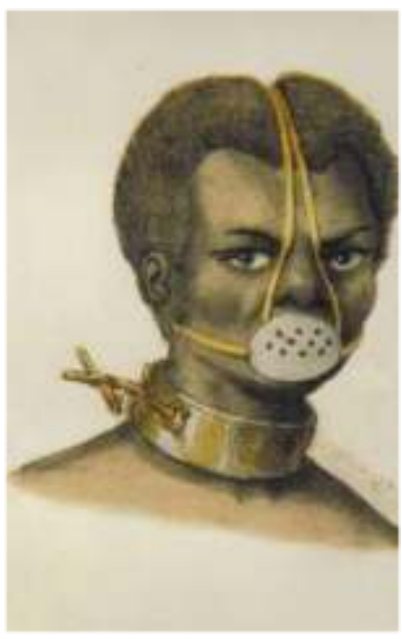

Castigo de escravos. Litografia aquarelada sobre papel. Sem medidas. 1839

Coleção Museu AfroBrasil

Essa aproximação com a produção de Rosana Paulino permite-nos formular algumas considerações bastante instigantes. Há nela uma intenção - também presente na arte de outras mulheres com viés feminista - de autorrepresentar seu corpo, suas experiências e memórias. Destaca-se a habilidade de reavaliar e de contestar categorias estanques, 
identidades cristalizadas e tidas como biológicas ou naturais. Nesse sentido, essa produção possui um caráter fortemente antirracista, que também debate temas contemporâneos como a exclusão, a violência física e simbólica contra o corpo feminino e a pobreza. Suas obras fazem desmoronar os discursos reiterados da mulata sensual, da negra exótica, da servidora, seja da escrava ama-de-leite ou a babá contemporânea. Desvinculam a experiência carnal das mulheres do regime visual masculino e explicitam corpos carregados de traumas e de rejeições: sua imagem que não é aceita por outros, mas também por si mesma -, a sexualidade que é explorada, o trabalho malremunerado etc. É instigante observar que artistas como Paulino tomam para si a tarefa de representação e de construção de si ao reagir às categorizações identitárias e fixadoras estabelecidas na sociedade de controle (DELEUZE, 1992: 219). Elas propõem práticas libertárias e radicais, tomando o corpo como um campo político, de incisão e subversão de forças e geram uma explosão de sentidos que arruína os universais simbólicos.

\title{
Claudia Contreras: memória, gênero e política nas artes visuais argentinas
}

\author{
(...) é mais importante entender do que lembrar, \\ embora para entender também seja preciso lembrar. \\ Beatriz Sarlo
}

24 A cena artística argentina, dos anos de 1980 até a atualidade, evidenciou inúmeros artistas que produziram intensamente, alinhados com efervescências artísticas e culturais de diversas cidades latino-americanas, sobrecarregadas de um passado recente violento, que ainda reverbera. Decorrente da transição democrática do país a partir do ano de 1983, a Argentina atravessou uma ampla tensão e mobilização social sob o governo do então presidente Raúl Alfonsín, que esteve no poder até 1989. Durante o governo democrático seguinte, de Carlos Saúl Menem, de 1989 a 1999, ocorreu um empobrecimento massivo da população que deixou no país cicatrizes sociais e econômicas profundas, ainda não de todo esquecidas.

Aliada a estes problemas sociais, a experiência do trauma e da violência de Estado, traçou nos corpos e subjetividades uma radicalidade impactante aos nossos olhos, derivada também da magnitude que atingiram na Argentina os processos de tortura e assassinato de militantes políticos durante a ditadura militar. Como pontua Viviana Usubiaga, nesse momento, elaborou-se um luto simbólico nas obras de arte, que problematizavam a representação do corpo nesse tempo de desaparecimentos humanos (USUBIAGA, 2012: 19).

Os movimentos feministas foram fundamentais na reconstrução democrática argentina. Tendo ganhado espaço durante a primeira metade dos anos de 1970, grupos de mulheres como a Unión Feminista Argentina (UFA) e o Movimiento de Liberación Femenina (MLF) foram amplamente reprimidos no contexto ditatorial, após o golpe militar de março de 1976, voltando à tona apenas nos anos de 1980, durante a redemocratização (BARRANCOS, 2007: 277-78). Essas mobilizações sociais de mulheres, ainda que não diretamente presentes nas discussões da arte, contaminaram as práticas artísticas nos anos subsequentes. Por outro lado, marginais e autônomas, as críticas feministas esparsas formuladas no contexto artístico dos anos de 1980 e 1990 fazem parte de uma história desconhecida, pouco abordada e valorizada pela escrita da história dominante. 
María Laura Rosa destaca que “(...) na Argentina, a teoria feminista é um mundo ainda não explorado e, portanto, não acompanhou os/as artistas contemporâneos/as em suas investigações, nem revisou exaustivamente o discurso da própria história da arte argentina" (ROSA, 2009: 125). Como no Brasil, ainda que o movimento feminista e os movimentos de mulheres tenham grande força no país, Rosa refere-se às iniciativas artísticas que apresentam um olhar político em relação às construções culturais do feminino. Segundo ela, são poucas as artistas que trabalham no país nessa perspectiva, destacando Silvia Gai (1959-) e Claudia Contreras e lembrando nomes como os de Ilse Fusková (1929-), Nora Aslan (1937-), Ana Gallardo (1958-) e Marta Ares (1961-). Existem também artistas que flertam com as temáticas de gênero no transcorrer de suas trajetórias como, por exemplo Nicola Costantino (1964-), Diana Dowek (1942-), Silvia Young (1949-1998), Liliana Maresca (1951-1994), Mirta Kupferminc (1955-), Carolina Antoniadis (1961-) e Fabiana Barreda (1967-).

27 A sexualidade experimentada mais livremente também foi tema de diversas obras a partir desses anos de abertura democrática, o que indica a necessidade de problematizar as imagens dos anos de 1980 e 1990 - sobretudo as produções artísticas de mulheres, mas também aquelas produzidas por homens e que incluem temáticas de gênero - a partir de sua potência política de crítica da cultura. Também se anuncia aí uma concepção de luta política mais abrangente e complexa, como apontada por diversas vertentes do pós-estruturalismo e dos feminismos, apenas visível por meio de uma análise das relações de poder cotidianas. Por exemplo, a preocupação de diversos artistas com a disseminação do HIV apresenta-se em obras que aludem à dor, à doença e ao preconceito social contra os homossexuais ou contra as mulheres. Muito além de um fechamento subjetivo sobre temas íntimos ou privados, essas imagens debatem as configurações da cultura ocidental, em sua capacidade de excluir e menosprezar aquilo que se encontra fora de suas normas.

Claudia Contreras é uma artista múltipla em suas formas de criar, destacando-se pela densidade de suas reflexões políticas, sobretudo no que se refere à experiência do terrorismo de Estado na Argentina. Dialoga com a colagem, a costura e a paródia, modulando sua voz crítica com dados que aludem à história do país. Realiza desenhos, pinturas, bordados, objetos, fotografias e animação digital. Muitas vezes, elementos aparentemente inocentes como pequenos exercícios para costura e bordado, presentes em manuais femininos antigos, são reinseridos em obras, ganhando um sentido contestador, pela mobilidade de contexto. Furar, coser, costurar - verbos de um sentido incólume quando ensinados às mulheres "domesticadas", pelo olhar atento de Contreras irão contar histórias de horror, de assassinatos e de desaparecimentos.

Há uma perspectiva analítica em construção sobre o uso transgressivo feito pelas artistas contemporâneas dos procedimentos tradicionais femininos, das artes das agulhas às manualidades domésticas, como nas produções aqui destacadas de Paulino e Contreras. Lilian Tone, ao abordar o fazer manual na construção da obra da artista brasileira Leda Catunda (1961-) - mas que pode ser estendido a diversas outras artistas da mesma geração - aproxima-o do conceito de femmage proposto pelas artistas e teóricas americanas Miriam Schapiro e Melissa Meyer. São práticas ligadas à manualidade e ao ambiente doméstico e historicamente feminino, tais como patchwork e colagem ou costura e culinária: "Híbrido de feminino e colagem, a ideia de femmage caracteriza uma produção artística sistematicamente excluída da corrente dominante. (...) Isto que, nas décadas de 1960-70, em plena efervescência do Women's Movement, não parecia ter sido 
levado a sério, ou não era considerado arte relevante, acabou por informar e infiltrar o pensamento crítico de forma essencial nas décadas subsequentes" (TONE, 2009: 25).

As chamadas artes aplicadas, na estruturação da história da arte como disciplina, foram assim relegadas a uma produção menor, tipicamente associada ao fazer executor das mulheres, em contraste com o poder criativo dos "grandes mestres". Como numa revanche, artistas como Contreras utilizam desses meios rotulados "menores" para compor críticas agudas à cultura, como ao abordar a História do século XX, os genocídios e as ditaduras latino-americanas, sobretudo em seu país. Suas obras carregam a tarefa da recuperação da memória como uma responsabilidade do presente. Em suas palavras, a arte busca "reparar el tejido social desgarrado, roto por la violencia del Terrorismo de Estado, y por las decisiones político-económicas, de los sucesivos gobiernos democráticos pos-facto" (CONTRERAS apud ROSA, 2009: 115).

No começo de sua formação como artista, entre 1974-76, Contreras estudou na Escuela Nacional de Bellas Artes de Quilmes e depois em Madri, na Espanha, a partir do ano de 1978, na Real Academia de Bellas Artes. Completou sua formação ao regressar para a Argentina em 1984, na Escuela Nacional de Bellas Artes Manuel Belgrano e na Escuela Superior de Bellas Artes Ernesto de la Cárcova. Iniciou sua produção numa linha conceitual em princípios da década de 1990, momento que a Argentina viu, ao lado do crescente neoliberalismo e do empobrecimento massivo da população, investimentos públicos e privados até então inéditos na produção artística.

Nessa década, ela produziu uma série de aquarelas em que se apropriou da imagem de moldes de costura que tomam o formato dos corpos. Chamada Patrones (Padrões, 1993-94), a artista cria um jogo de ironias entre as orientações tradicionalmente presentes nos manuais para costura e os enunciados sociais, por exemplo, quando numa construção imaginária do corpo do país, indica: "localize o olhar fazendo cortes em toda a extensão para que não franza o forro".

Imagem 08 - Claudia Contreras, Patrones, 1993-94, tinta e aquarela sobre papel Canson, 29x21 cm

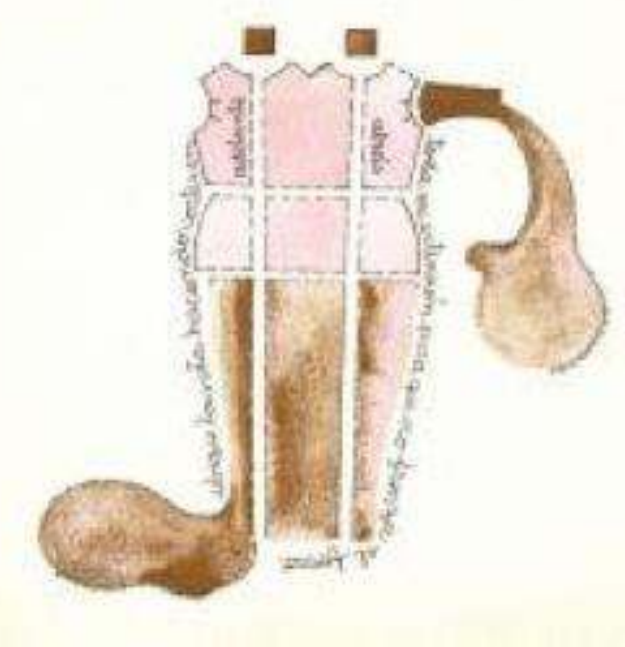

Essas frases que originalmente eram impressas nos moldes de roupas, como meio de ensinar a costurar, aqui ganham um sentido de crítica bastante instigante. Contreras 
revisita esse material a priori apolítico, pinçando duplos sentidos e imagens poéticas que se associam ao passado argentino, sobretudo às torturas e desaparecimentos. Notemos que nesses moldes, algo como tumores parecem surgir nas extremidades, num estranhamento do corpo social que permite leituras sobre a construção e fragmentação dessa história que necessita ser re-costurada.

A série Historias Clínicas, de 1994-95, caminha em um sentido próximo, pois a artista trabalha sobre outra imagem inocente: os mapas escolares. Neste momento, começa a manipular o mapa da Argentina, em desenhos muito delicados e complexos, que "refletem a enfermidade encarnada na geografia nacional" (LAURÍA, 1998). Essa associação entre o território da nação e o corpo atacado por uma agressão que aparece como congênita surge em obras como País Generoso, Hipertrofia, El grano em el culo, Columna vertebral, Virus.

$\mathrm{Na}$ imagem Columna Vertebral, Contreras associa a coluna vertebral- eixo de sustentação do corpo - a dentes humanos. A Argentina aparece então como um país que carrega em si marcas da morte: os dentes, último recurso usado para a identificação dos corpos. Na obra El grano en el culo, a artista mostra as Ilhas Malvinas (Falkland Islands) como o problema que ainda marca e persegue a memória política do país. Uma guerra contra o Reino Unido foi usada como tentativa de demonstração de poder da Argentina, em 1982, onde centenas morreram em nome de uma disputa pela soberania do arquipélago no Atlântico Sul. A disputa para a reintegração do território ao extremo sul do continente, em que a Argentina saiu derrotada, foi um dos fatores que deslegitimou a Junta Militar que governava o país naquele momento e contribuiu para a restauração da democracia argentina.

Em Argentina Corazón (1994-95), a artista redesenha o mapa da Argentina como um coração, com seus rios sendo veias e artérias, criando um sentido poético bastante denso. Ela não concebe o território como um domínio objetivo do Estado, mas como um organismo vivo, passível de enfermidades e de choques. Esse modo conceitual de lançar um olhar sobre a história promove um deslocamento de forte crítica política e de importante dimensão afetiva. O sangue também corria nos rios do país - dramáticas lembranças dos vuelos de la muerte sobre o mar ou sobre o Río de la Plata. 
Imagem 09 - Claudia Contreras, Columna Vertebral

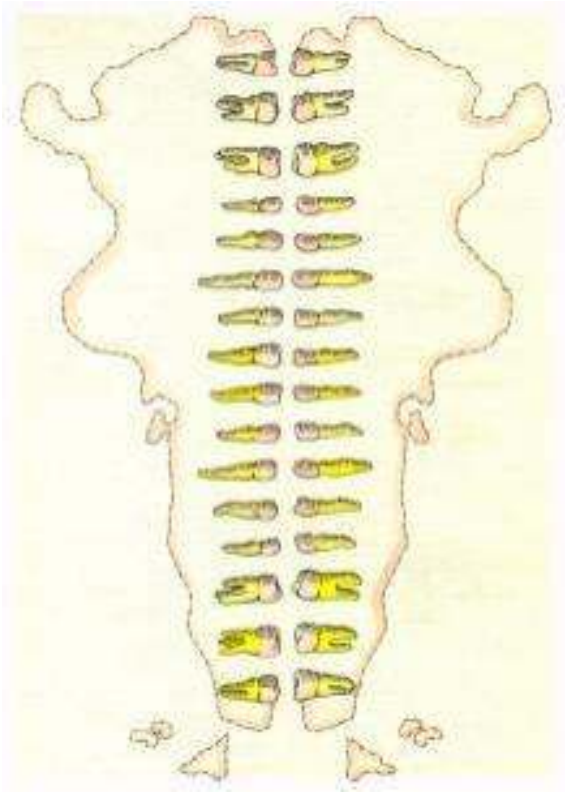

Série Historias Clínicas,1994, tinta e aquarela sobre papel Canson, 28,5×21cm.

Imagens 10 - Claudia Contreras, El grano en el culo

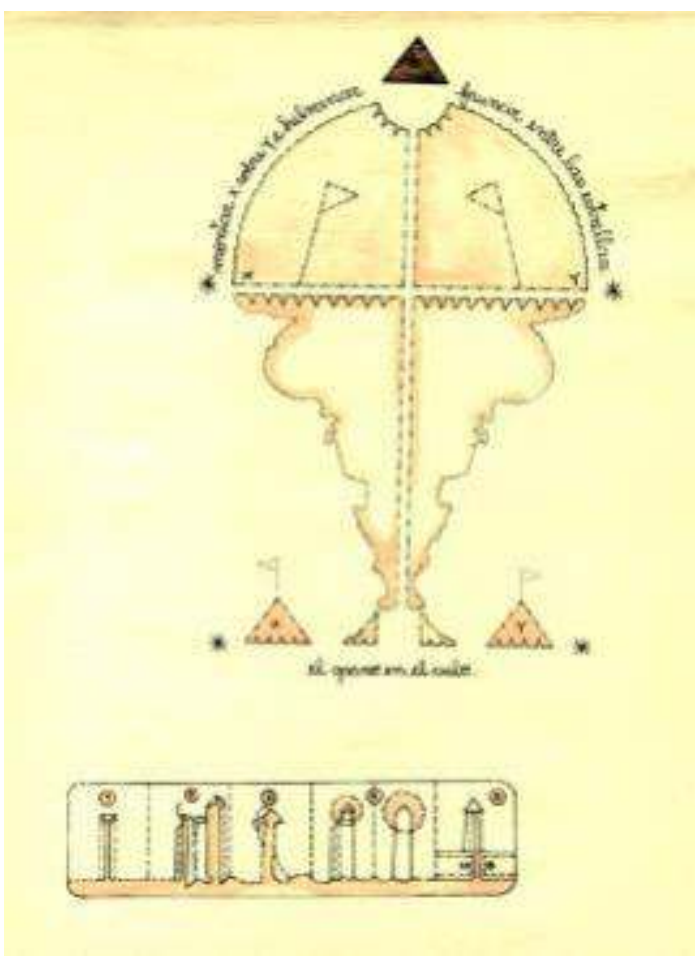

Série Historias Clínicas, 1994-95, tinta e aquarela sobre papel Canson, 28,5×21cm. 
Imagens 11 - Claudia Contreras, Argentina Corazón

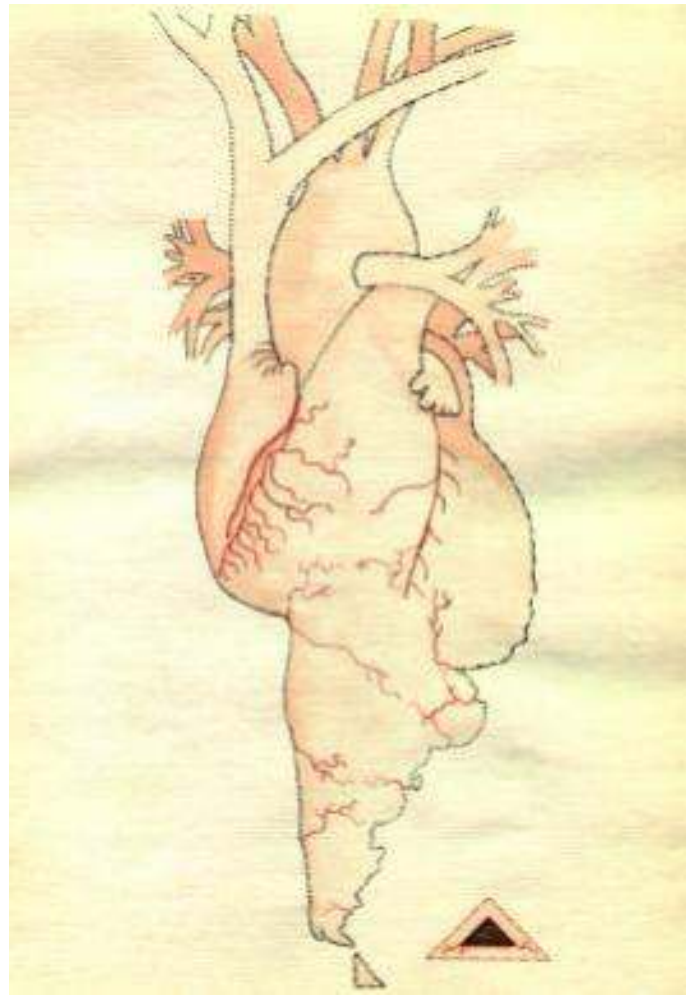

Série Historias Clínicas, 1994-95, tinta e aquarela sobre papel Canson, 28,5×21cm.

Em outra série de Contreras, não apenas a Argentina é percebida como um organismo vivo, mas, num nível microscópico, a política e o poder residem na superfície dos corpos. Na exposição Como carne y uña, em 1998, ao lado da artista Cristina Piffer, ela apresenta a instalação ALMAS, exibindo cabides originalmente utilizados para biquínis como base para um tecido transparente e branco, com imagens singulares. Esses cabides delicados são suspensos e pairam como fantasmas, almas, no espaço expositivo. Neles, são bordados desenhos de estruturas orgânicas humanas e prédios e instituições militares argentinas. 
Imagens 12 e 13 - Claudia Contreras, Almas, 1998, detalhes ESMA. Bordado e aquarela, tecido e cabides de metal, medidas variáveis
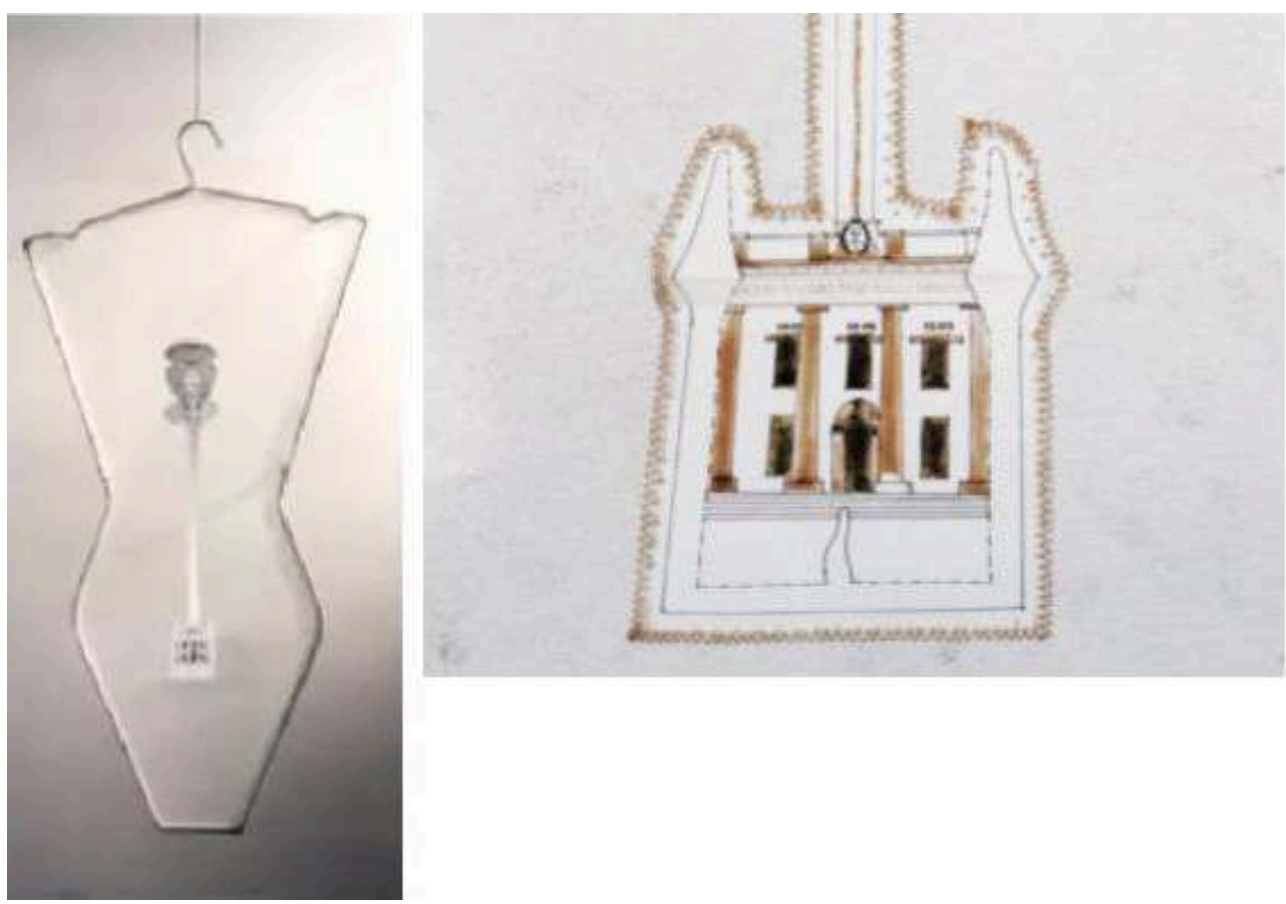

Contreras constrói um olhar sobre a arquitetura do poder, mostrando prédios militares utilizados para encarcerar, interrogar e torturar os presos políticos, como testemunhos vivos dos anos de ditaduras militares que marcam a paisagem da cidade ainda hoje. A Escuela de Mecânica de la Armada (ESMA), um dos mais emblemáticos e abomináveis edifícios do período, está bordada sobre as zonas genitais em um dos cabides. Ela está conectada, nessa superfície, à bordados de estruturas orgânicas - como ao cérebro transferido para a altura do coração - numa aproximação imaginária em que o corpo é um conjunto das experiências vividas, coletivas e também individuais.

Imagem 14 - Claudia Contreras, Almas, 1998. Bordado e aquarela, tecido e cabides de metal, medidas variáveis

$\mathrm{Na}$ Argentina e em outros países marcados por acontecimentos traumáticos, vive-se em tempos de "explosão da memória" ou, nas palavras de Suely Rolnik, num "furor de arquivo" (ROLNIK, 2009 e NORA, 1993). Grupos políticos em cidades como São Paulo, Berlim, Buenos Aires e Santiago têm refletido sobre a necessidade de dialogar sobre o espaço urbano, compreendendo-o como uma ferida aberta que expressa memórias das ditaduras, extermínios e violações aos direitos humanos. A arte propõe um modo de articular essas experiências por meio da dimensão afetiva, criando uma memória ativa fundamental para a construção democrática. Horacio González, ao pensar sobre esse impasse da construção da memória do horror por meio da arte, aponta para algumas das contradições que se apresentam, por exemplo, em relação à ESMA: "É difícil fazer hoje um balanço desta experiência artística que corre o risco de seu forte abstracionismo e ao mesmo tempo a maravilha de ser como um museu dos últimos alicerces da condição humana e dos labirintos perdidos da memória. Em primeiro lugar, para seu próprio esclarecimento essa arte deve encarregar-se da dialética das ruínas: a arqueologia trabalha com a memória em estado petrificado e é necessário construir um pensamento vitalista sobre as ruínas" (GONZÁLEZ, 2010:233). 
40 Nesta e em outras séries, Contreras abordou os temas da memória social, problemática longe de ser resolvida nas sociedades contemporâneas. Ela tece suas críticas por meio do uso dos trabalhos manuais femininos (o bordado, a costura, os moldes de roupas), evidenciando a permanência de discursos opressores. Vale destacar esse uso que condensa um modo bastante sensível de se compreender a memória, sempre em conexão com os corpos, numa reconstrução ativa que põe em diálogo constante o público e o privado. Nelly Richard indica, numa perspectiva coincidente, que a memória em construção é uma das importantes arenas políticas na atualidade, denotando uma insatisfação social com os discursos hegemônicos, que também se expressa por meio da arte: "A memória agita o dado estático do passado com novas significações (...). E é o trabalho laborioso dessa memória insatisfeita, que não se dá nunca por vencida, a que perturba a vontade de sepultamento oficial da recordação vista simplesmente como depósito fixo de significações inativas" (RICHARD, 2001: 29-30).

41 Podemos recorrer ainda a Foucault, quando compreende a conformação política moderna enquanto um controle do corpo das populações, que exigia cuidado e disciplina, para além dos corpos individuais (FOUCAULT, 2001). A artista evidencia também essas estratégias de controle social, jogando com as imagens de inocentes moldes de costura ou mapas de territórios como os usados nas escolas. Nesse caminho, confronta os enunciados misóginos que consideram o espaço privado da casa como ausente de possibilidades de leitura política, compondo uma instigante análise da conjuntura argentina sem abdicar do valor das memórias individuais e de percorrer as tramas que historicamente mantiveram as mulheres separadas da arena pública.

\section{Conclusão: tramas do corpo e da memória}

As poéticas das duas artistas aqui abordadas apresentam-se como práticas fluidas e em constante reelaboração, sendo atuantes na produção da cultura de sua época. Pensando a construção da subjetividade feminina, elas discutem e produzem críticas feministas atuais, impulsionando nomadismos identitários e provocando riso perante categorias fixas e hierárquicas.

43 Rosana Paulino e Claudia Contreras formulam, assim, um tipo de pensamento marcado pela experiência, pelo corpo, pelo afeto e pela memória. Suas obras perscrutam nossa cultura, compreendendo os mecanismos através dos quais o poder racista, sexista e classista é exercido e mantido - da micropolítica às práticas de guerra - exame necessário para que novos espaços de convivência éticos sejam possíveis.

A discussão entre o histórico e o contemporâneo, entre autorrepresentação e representação imposta é fundamental para a discussão das artistas negras na atualidade, como Paulino. Produzir uma arte feminista e antirracista, nessa perspectiva, intenta desestruturar as bases simbólicas do preconceito racial, a partir de uma valorização da experiência e cultura negras que revise criticamente o imaginário que é constituinte das subjetividades. Essa atitude crítica também está presente em Contreras, que traz à tona os temas da sexualidade, das feridas sociais e das marcas da violência que ainda hoje permeiam a cultura argentina. Em suas obras, o corpo é compreendido em confluência com a memória - instável, fragmentada e seletiva. O corpo dá sentido à memória profunda e ao sofrimento compartilhado, sendo justamente o caráter coletivo dessa experiência que permite ressignificá-la e reconstruir a memória social esfacelada. 
Analisando a trajetória dessas duas artistas latino-americanas, destaca-se como a arte desfaz sentidos e práticas culturais naturalizadas, desconstrói imagens estáticas dos papéis de gênero e convida a uma maior percepção da constituição de si. Essas reflexões conectam-se a inúmeros desdobramentos politica e eticamente relevantes em nosso tempo e indicam novos campos de investigação relativos à história das mulheres artistas em países como Brasil e Argentina que têm sido recentemente explorados.

\section{BIBLIOGRAFÍA}

ALVAREZ, Sonia E. “Um outro mundo (também feminista...) é possível: construindo espaços transnacionais e alternativas globais a partir dos movimentos". Revista Estudos Feministas, Florianópolis, v. 11, n.2, p. 533-540, dez. 2003. Disponível em: . Acesso em 03 mar. 2011.

ARFUCH, Leonor. O espaço biográfico: dilemas da subjetividade contemporânea. Rio de Janeiro-RJ: Ed. da UERJ, 2010.

AZEVEDO, Célia Maria Marinho de. Onda negra, medo branco: o negro no imaginário das elites século XIX. Rio de Janeiro: Paz e Terra, 1988.

BAMONTE, Joedy. Legado: Gestações da Arte Contemporânea: Leituras de Imagens e Contextualizações do Feminino na Cultura e na Criação Plástica. Tese (Doutorado em Ciências da Comunicação) - Escola de Comunicação e Artes, Universidade de São Paulo, São Paulo, 2004.

BARRANCOS, Dora. Mujeres en la sociedad argentina. Una historia de cinco siglos. Buenos Aires: Editorial Sudamericana, 2007.

BRITO, Benilda Regina Paiva de. "Sociedade: Mulher, negra e pobre - A tripla discriminação". Teoria e Debate, no36, out/dez. 1997. Disponível em: . Acesso em 20 ago. 2011.

BRUIT, Héctor. “A Invenção da América Latina”. Anais Eletrônicos do V Encontro da ANPHLAC, Belo Horizonte, 2000.

CANTON, Katia. Novíssima arte brasileira: um guia de tendências. São Paulo: Iluminuras, 2001.

Catálogo Manobras radicais. (Curadoria de Heloisa Buarque de Hollanda e Paulo Herkenhoff). São Paulo: Centro Cultural Banco do Brasil, 2006.

CHIARELLI, Domingos Tadeu. Arte Internacional Brasileira. São Paulo: Lemos Editorial, 1999.

CHIRON, É. \& LELIÈVRE, Anaïs (Orgs.). L'intime, le privé, le public dans l'art contemporain. Paris : Publications de la Sorbonne, 2012.

CONTINENTINO, Ana Maria Amado. "Derrida e a diferença sexual para além do masculino e feminino”. In: DUQUE-ESTRADA, Paulo César (org.). Às margens: a propósito de Derrida. Rio de Janeiro: Ed. PUC-Rio; São Paulo: Loyola, 2002.

CONTRERAS, Claudia. "Señores Jurados del 58Salón Nacional de Rosario". Memoria Descriptiva de la obra "Vasos Argentinos", Carta inédita, Buenos Aires, 2005 apud ROSA, María Laura. La idea de pasado y el valor del presente en el arte contemporáneo. TESINA. Departamento de Historia del Arte. Facultad de Geografía e Historia. Universidad Nacional de Educación a Distancia. Buenos Aires/ Madrid, 2009. 
DE DIEGO, Estrella. "Durante El feminismo de la igualdad: Historiografía, teoría y prácticas artísticas”. Exitbook: feminismo y arte de género, n.9, Madrid, 2008.

DELEUZE, Gilles. Conversações, 1972-1990. São Paulo: Editora 34, 1992. [Edição francesa. Pourparlers 1972 - 1990, Paris : Les éditions de Minuit, 1990].

DELEUZE, Gilles \& GUATTARI, Félix. Mil Platôs: capitalismo e esquizofrenia, vol. 4. São Paulo: Editora 34, 1997. [Edição francesa. Mille Plateaux-Capitalisme et schizophrénie 2, Paris : Les éditions de Minuit, 1980].

FAZZOLARI, Cláudia. "Da estratégia ficcional/da poética visual para o gênero feminino na contemporaneidade: Carmen Calvo, Rosângela Rennó, Rosana Paulino e Ana Prada”. In: Anais do Seminário Internacional Fazendo Gênero 7, UFSC, Florianópolis, ago. 2006. Disponível em: <http:// www.fazendogenero.ufsc.br/7/artigos/C/Claudia_Fazzolari_35.pdf>. Acesso em 02 mai. 2010.

FIALHO, Ana Letícia. “AS EXPOSIÇÕES INTERNACIONAIS DE ARTE BRASILEIRA: discursos, práticas e interesses em jogo”. Sociedade e Estado, Brasília, v. 20, n. 3 p. 647-688, set./dez. 2005.

FOUCAULT, Michel. A coragem da verdade: o governo de si e dos outros II. Curso no Collège de France (1983-1984). São Paulo: Martins Fontes, 2011. [Edição francesa. Le Gouvernement de soi et des autres II: Le Courage de la vérité. Cours au Collège de France (1983-1984), Paris : Gallimard, 2009]

FOUCAULT, Michel. “Les techniques de soi”. In: Dits et écrits, Vol. IV. Paris : Gallimard, 1994, p. 783-813.

FOUCAULT, Michel. História da Sexualidade I: A Vontade de Saber. 14ª ed., Rio de Janeiro: Edições Graal, 2001. [Edição Francesa. Histoire de la sexualité, vol. 1: La volonté de savoir, Paris : Gallimard, 1976].

GONZÁLEZ, Horacio. “Arte, grito y representación: entre la abstracción universalista y los nombres de la história”. In: BIRLE, Peter (Ed.) Memorias urbanas en diálogo: Berlín y Buenos Aires. Buenos Aires: Buenoslibros, 2010.

JAREMTCHUK, Dária. “Ações políticas na arte contemporânea brasileira”. Concinnitas, Rio de Janeiro, UERJ, v. 1, n.10, p. 86-95, jul. 2007.

LARA, Silvia Hunold. Campos da violência: escravos e senhores na capitania do Rio de Janeiro, 1750-1808. Rio de Janeiro: Paz e Terra, 1988.

LAURÍA, Adriana. "La violencia congénita argentina según dos artistas". Página/12, Buenos Aires, 24 mar. 1998.

NORA, Pierre. “Entre Memória e História: A problemática dos lugares”. Revista Projeto História, São Paulo, n.10, p.7-28, dez. 1993.

PAULINO, Rosana. "Entrevista de Rosana Paulino". Catálogo Panorama de arte atual brasileira/97. (Texto crítico Tadeu Chiarelli; comentário Rejane Cintrão; apresentação Milú Villela). São Paulo: MAM, 1997.

PAULINO, Rosana. Imagens de sombras. Tese (Doutorado em Artes Visuais) - Escola de Comunicação e Artes, Universidade de São Paulo, São Paulo, 2011.

POLLOCK, Griselda. "Visión, voz y poder: historias feministas del arte y marxismo". In: CORDERO, Karen; ROMERO, Sáenz (Comps.). Crítica Feminista en la teoría e Historia del arte. Universidad Iberoamericana: México, 2007.

POLLOCK, Griselda. Encuentros en el museo feminista virtual: tiempo, espacio y el archivo. Madrid: Ediciones Cátedra, 2010. 
RAGO, Margareth. Os Prazeres da Noite: Prostituição e Códigos da Sexualidade Feminina em São Paulo (1890-1930). Rio de Janeiro, 1991, Paz e Terra.

RECKITT, Helena \& PHELAN, Peggy. Art and Feminism. New York: Phaidon, 2006.

RICHARD, Nelly. Residuos y metáforas: ensayos de crítica cultural sobre el Chile de la Transición. $2^{\mathrm{a}}$ ed. Santiago, Chile: Editorial Cuarto Propio, 2001.

ROLNIK, Suely. "Furor de arquivo". Revista do Programa de Pós-Graduação em Artes Visuais - EBA [UFRJ], Rio de Janeiro, ano XVII, n. 19, p. 97-105, $2009 \mathrm{~b}$.

ROSA, María Laura. “Las/os invisibles a debate”. In: ELIZALDE, Silvia; FELLITI, Karina; QUEIROLO, Graciela (Coords.). Género y sexualidades en las tramas del saber: revisiones y propuestas. Buenos Aires: Libros del Zorzal, 2009.

SARLO, Beatriz. Tempo Passado: cultura da memória e guinada subjetiva. São Paulo: Companhia das letras, 2007.

SIMIONI, Ana Paula Cavalcanti. "Baordado e transgressão: questões de gênero na arte de Rosana Paulino e Rosana Palazyan”. Revista Proa, Campinas, IFCH/UNICAMP, no 2, vol. 01, 2010.

SOBRAL, Cristiane. Não vou mais lavar os pratos. Brasília: Athalaia, 2010.

TELLES, Norma. "Fios Comuns". Estudos de literatura brasileira contemporânea: questões de gênero, Brasília, nº32, p. 115-125, jul./dez. 2008.

TONE, Lilian. "Leda Catunda: entrevista comentada". Catálogo Leda Catunda, 1983-2008. São Paulo: Pinacoteca do Estado, 2009.

TVARDOVSKAS, Luana S. Figurações feministas na arte contemporânea: Márcia X., Fernanda Magalhães e Rosângela Rennó. Dissertação (Mestrado em História) - Instituto de Filosofia e Ciências Humanas, Universidade Estadual de Campinas, Campinas, 2008.

TVARDOVSKAS, Luana S. Dramatização dos corpos. Arte contemporânea de mulheres no Brasil e na Argentina. Tese (Doutorado em História) - Instituto de Filosofia e Ciências Humanas, Universidade Estadual de Campinas, Campinas, 2013.

USUBIAGA, Viviana. Imágenes inestables: artes visuales, dictadura y democracia en Argentina. Buenos Aires: Edhasa, 2012.

\section{NOTAS}

1. No século XIX a sexualidade feminina foi patologizada, o prazer das mulheres negado e a histeria converteu-se no modo dominante de interpretar as reações indesejadas das mulheres perante a cultura masculina. RAGO, Margareth. Os Prazeres da Noite: Prostituição e Códigos da Sexualidade Feminina em São Paulo (1890-1930). Rio de Janeiro, 1991, Paz e Terra.

2. Falogocentrismo, conceito proposto por Jacques Derrida, indica que o logos e o phallus adquirem uma estreita relação metafórica no mundo ocidental. o conceito é utilizado por diferentes pensadoras feministas como Judith Butler, Luce Irigaray e Hélène Cixous, indicando as conexões entre os sistemas de pensamento e o gênero. Cf. CONTINENTINO, Ana Maria Amado. Derrida e a diferença sexual para além do masculino e feminino. In: DUQUE-ESTRADA, Paulo César (org.). Às margens: a propósito de Derrida. Rio de Janeiro: Ed. PUC-Rio; São Paulo: Loyola, 2002. 


\section{RESÚMENES}

Esse artigo propõe analisar as produções das artistas contemporâneas Rosana Paulino (São Paulo, Brasil, 1967-) e Claudia Contreras (Buenos Aires, Argentina, 1956-) que criticam práticas misóginas, apresentando um espaço privilegiado de intersecção com o pensamento feminista. Suas experimentações artísticas oferecem elementos para a compreensão das relações entre arte e gênero na América Latina e são exemplos de tensões culturais e de intervenções críticas que atravessam diferentes mulheres artistas na atualidade.

Cet article se propose d'analyser le travail de deux artistes contemporaines, Rosana Paulino (Sao Paulo, Brésil, 1967) et Claudia Contreras (Buenos Aires, Argentine, 1956) dont les œuvres critiquent les pratiques misogynes et présentent un lien privilégié avec la pensée féministe. Leurs expériences artistiques offrent des éléments pour comprendre la relation entre l'art et le genre en Amérique latine, et prennent comme exemples des tensions culturelles et des interventions critiques qui touchent différentes femmes artistes aujourd'hui.

\section{ÍNDICE}

Palabras claves: mulheres artistas, feminismo, Brasil, Argentina, Claudia Contreras e Rosana Paulino

Mots-clés: femmes artistes, féminisme, Brésil, Argentine, Claudia Contreras, Rosana Paulino

\section{AUTOR}

\section{LUANA SATURNINO TVARDOVSKAS}

Luana Saturnino Tvardovskas é Doutora em História Cultural pela UNICAMP, Campinas-SP, orientada pela Dra. Luzia Margareth Rago. É autora da tese (Dramatização dos corpos: arte contemporânea de mulheres no Brasil e na Argentina), além de capítulos de livros e artigos discutindo corpo, gênero, arte contemporânea, feminismo, subjetividade e relações de poder. 